IN MEMORIAM: HANS ANKUM (1930-2019)

Hans (Johan Albert) Ankum was born on 23 July 1930 in a family originally coming from Germany ${ }^{1}$ with a socialist background. His father was appointed burgomaster in Koog aan de Zaan, a small town north of Amsterdam in 1946 and his mother was a teacher of French. He was the elder of two brothers. After secondary school in Zaandam, where he studied Greek and Latin, he studied law at the Amsterdam Municipal University. He hesitated momentarily because of his musical talents. The Conservatory could be another attractive option, but he eventually chose the law faculty in the Municipal University of Amsterdam as his future domain. Among his Amsterdam teachers were Marcel Henri Bregstein (1900-1957), a brilliant professor of private law, and Hendrik Richard Hoetink (1900-1963), professor of Roman law. He certainly was a very good student and after his master's degree (1953) he went to Paris with a Dutch scholarship where he lived in the Dutch Pavilion in the Cité Universitaire for two years (1954-1956). There he started the research for what was to be a voluminous doctoral thesis on the actio Pauliana and its history. ${ }^{2}$ Moreover, he made many friends amongst the French Romanists and legal historians. After 1956 he was an assistant of Professor Hoetink.

1 Ankum is a small village in Lower Saxony near Osnabrück. For biographical information see, also, CH van Rhee \& LC Winkel (2011): "Een Romeinsrechtelijke coryfee - Rechtshistorici in de Lage Landen (11): Interview met Hans Ankum in Pro Memorie" 12(2): 146-168.

2 JA Ankum (1962) De geschiedenis der actio Pauliana (Zwolle) 491pp with a summary in French. 
In 1960 he was appointed as a lecturer in legal history in Leyden. In 1962 he defended his thesis in Amsterdam for which he was awarded with the highest distinction cum laude. At the same time he published a book on the development of the actio Pauliana in the nineteenth century. ${ }^{3}$ Both books are remarkable accomplishments. In his thesis he devoted not only attention to classical Roman law, but he also covered medieval doctrine since the glossators, and old French and Dutch law until the nineteenth century codification. In his second book he was a forerunner of the legal historians interested in the legal history of the nineteenth century - at that time still nearly undiscovered. In 1963 he was appointed as a professor for legal history at the University of Leyden and in 1965 he was called back to the chair of Roman law, legal history and juristic papyrology at the Municipal University of Amsterdam as a successor of his promotor Hoetink who passed away in 1963. There he taught the important courses in the first year of Roman law and legal history. Hans Ankum was a brilliant teacher. He used to lecture in the biggest audience hall of the law faculty and he inspired many students. He retired in 1995 and received studies in his honour in two volumes. ${ }^{4}$ His output was impressive: two books of his collected articles were published. ${ }^{5} \mathrm{He}$ mastered several foreign languages which facilitated his many contacts abroad. He became the informal co-ordinator of the yearly SIHDA conferences, especially after the death of his friend Aristide Theodoridès in 1994.

His method consisted of a thorough analysis of the Roman legal sources, taking into account their palingenetic origin. Moreover, he was often aware of non-legal issues that were important for Roman jurists, ${ }^{6}$ although he published mainly in the realm of classical Roman law and occasionally on later legal history. He was not influenced by the spell of the doctrine of extensive interpolations. In this respect he followed the example of his promotor Hoetink, who in his doctoral thesis (1928), was already careful in assuming Justinianic interpolations in the Digest. ${ }^{7}$ After 1967, the year of the conference La critica del testo, this theory - or rather, the ideology of interpolations - turned out to be an outdated paradigm, mainly based on exaggerate standards imposed upon the Latin used by the Roman jurists. Hans Ankum often

3 JA Ankum (1962) De Pauliana buiten faillissement in het Nederlands recht sedert de codificatie (Zwolle): 246pp with a summary in French.

$4 \quad$ R Feenstra et al (eds) (1995) Collatio ivris romani - Etudes dédiées à Hans Ankum à l"occasion de son $65^{e}$ anniversaire (Amsterdam) I-II 710pp.

5 Hans Ankum (2007) Extravagantes - Scritti sparsi sul diritto romano (a cura di Carla Masi Doria e Johannes Emil Spruit) (Napoli) 531pp; Hans Ankum (2014) Nueva antología Romanistística (Madrid) 430pp.

6 "Griekse invloeden op het Romeinse recht en de Romeinse rechtswetenschap" Lampas 1982: 331-340.

7 HR Hoetink (1928) Periculum est emptoris (Haarlem) dissertation under the supervision of JC van Oven in Leyden. 
stressed the individualism of the Roman jurists, for example very clearly in brilliant articles on Papinian. ${ }^{8}$

Hans Ankum was an example of informal leadership. In Amsterdam he formed a group of assistants who were bound by friendship and mutual interest. He was always very helpful, his door was open and he had a talent to attract very different people. It was never too much for him to provide colleagues, especially in Eastern Europe where library facilities were not as good as in the Netherlands, with copies of articles. I still see him after normal office hours behind the copying machine. Among his many pupils are Arthur Hartkamp, author of a brilliant thesis on classical Roman law, later equally brilliant in private law, eventually Procureur Generaal at the Dutch Supreme Court and a key figure in the recodification of Dutch private law (1992); Peter Kop, later judge in the Dutch Supreme Court; and Eric Pool, later professor at the Free University in Brussels.

Hans Ankum was justly honoured on several occasions: In 1986 he was elected as a member of the Royal Dutch Academy of Sciences where only one active representative of each branch of studies may be nominated. In 1992 he was bequeathed by the Queen with the high decoration "Ridder Nederlandse Leeuw". Several universities, especially Eastern European Universities, bestowed honorary doctorates on him: for example Brussels Free University, Aix/Marseille, Bochum, Prague, Belgrade, Sofia (UNWE) and Murcia.

His last years were not easy: he suffered from health problems, mental and corporeal, which required rather long periods of hospitalisation after 2016. He passed away quietly on June 3, 2019 after an evening concert in his beloved Concertgebouw.

He was a great and admirable successor of the equally famous Dutch legal humanists of the seventeenth century.

Laurens Winkel

\section{IN MEMORIAM: HANS ANKUM}

Professor Hans Ankum was the Honorary Editor of Fundamina for many years. During all these years he supported and assisted Fundamina. A Journal of Legal History, the journal of the Southern African Society of Legal Historians. He published articles in our journal and also supported members of our Society when publishing and presenting papers abroad.

We knew Professor Ankum as someone who could always be approached for assistance. In addition, we also knew that he was an academic who put his heart and soul into his work, and worked for many more hours per day than most of his

8 "Le laconisme extrême de Papinien" (1994) Estudios de Historia del Derecho Europeo in Homenaje al Professor G Martínez Diez (Madrid): 43-61 = Extravagantes, 279-297; (1996) "Papinian, ein dunkler Jurist?" Orbis Iuris Romani 2: 5-32. 
colleagues. He furthermore had a good sense of humour and was a true lover of the good life, and often the soul of a party.

Professor Ankum always had time for his colleagues - young and old. Especially the young ones benefited, for he always had time for them too. I will never forget the first SIHDA Conference that I attended in Turkey. My colleague and I were intimidated by all the senior professors, but he encouraged and supported us. And almost thirty years later we saw him do the same to our new and young colleagues.

We will miss you, Hans.

Rena van den Bergh

(Editor of Fundamina 1996-2018) 